\title{
PROBLEMS AND PROSPECTS OF THE INNOVATION MANAGEMENT DEVELOPMENT IN UKRAINE
}

\author{
Nataliia Gliebova ${ }^{1}$ \\ Viktoriia Kovalova ${ }^{2}$
}

DOI: https://doi.org/10.30525/978-9934-588-15-0-26

Abstract. Entrepreneurial development has become increasingly innovative in successful, developed countries over the last decades. Moreover, the innovative processes in these countries have comprehensively extended to all spheres of activity. It is an innovation that leads to the value creation, productivization and economic growth. Due to this, the problems of development of innovative entrepreneurship in Ukraine have become even more urgent in recent years. It is a reflection of the growing understanding of society that the restoration of Ukraine, all socio-economic spheres of its life, will be possible due to the innovative development scenario. This scenario assumes that the model, which creates the fundamentally new management systems is crucial to the success of economic activity, rather than the management algorithms for the efficient allocation of available resources. The subject of the article's research is the analysis and generalization of the problems and prospects of innovative management development in Ukraine. The purpose of this article is to analyze the factors that directly or indirectly affect the development of innovative management in Ukraine. The article examined the innovative potential of Ukraine, its place in the ranking of assessing the innovative development of countries according to the Bloomberg innovation index. Potential opportunities of Ukraine in innovative activity are considered. The regions with the highest innovation activity, types of innovations and the amount of expenses spent by the Ukrainian enterprises on innovations are statistically analyzed. The business environment factors (such as financial, economic, political and

\footnotetext{
${ }^{1}$ Candidate of Economic Sciences, Associate Professor, Department of Management and Administration, National Pharmaceutical University, Ukraine

${ }^{2}$ Candidate of Economic Sciences, Associate Professor, Department of Management and Administration, National Pharmaceutical University, Ukraine 
legal, human, technological, organizational and infrastructural) that do not contribute to the development of innovation in the country were analyzed. Management of innovations involves the use of innovation management, in connection with this, the essence and main functions of the innovation management were analyzed. The role of the manager increases during the innovative activity. He/she must be a creative, original personality, because that such kind of a person can use and support innovation management. The article examined the main features of creative managers, identified specific tasks that they shall solve. Also the problems of creativity development among managers (at the state level, at the level of a hotel business entity and at an individual level) were analyzed at different levels. Innovation management implies the accumulation of innovative ideas, bringing innovative ideas to the level of a finished product or technology. In this regard, it is necessary to use creativity as the ability to come to new, non-trivial and, at the same time, justified decisions. The article substantiates that, on the basis of the creative component, the features of the managerial activity engaged in the innovative activities are modified and this creativity is the basis of innovation management. In addition, the peculiarities of the creative work of the staff were determined and the characteristics that induce the tendency of employees of an enterprise to be creative were identified. Nowadays, at the modern stage, new educational institutions are needed to train the creative managers. So far, the necessity for creation of the entrepreneurial university, which should be aimed at: the generation of creative thinking, knowledge, study of new areas; the development of innovative teaching methods and introduction of the knowledge into practice using various types of interaction with the external environment is increasingly iscussed.

\section{Introduction}

At the Global Innovation Index press conference held in Geneva in 2017, the Director General of the World Intellectual Property Organization F. Harry's report emphasized that in a global economy increasingly driven by knowledge, innovations are the engines of economic growth, they help to stimulate the realization of creative abilities and increase the production output [14].

Innovation is a defining characteristic of modern scientific and technological, industrial, socio-economic and all social processes and is highly relevant for Ukraine. Whether the country will move in the direction of 
joining the developed countries, or remain a moaning country on the sidelines of scientific, technological and social progress, depends on the mastery of innovative development mechanisms. As for Ukraine, which economy nowadays takes the form of de-industrialization, the activation of innovative activity is a necessary, crucial condition for its further development. Describing the current situation in the innovation field, domestic experts equate its development to the 90 -s of the twentieth century, when the economy was characterized by a significant stagnation of the industrial production [3]. However, for the development and implementation of innovation in practice, the enterprise must be headed by a creative thinking manager who uses innovation management in his managerial activity and maintains a creative, innovative atmosphere in the team. That is why all of these components must be observed.

\section{Innovative potential of Ukraine}

In 2019, Bloomberg, which is one of the most influential news agencies in the world, published a rating to assess the innovative development of countries. It evaluates the innovation of economies based on a number of criteria such as:

- R\&D expenditure relative to GDP;

- productivity;

- the percentage of high-tech companies in the total number of enterprises;

- number of scientists per million inhabitants;

- added manufacturing value in relation to GDP;

- percentage of secondary graduates enrolled in postsecondary institutions in the total number of graduates of educational institutions and

- patent activity.

The leader of the most innovative countries in the world according to Bloomberg is once again South Korea. Germany rose in the ranking by two positions and took the 2nd place. Finland ascended four positions and finished third. The top five also included Switzerland and Israel. The United States of America returned to the top 10 compared to 2018, when they lost their position due to the low educational index.

In 2019, Ukraine was ranked 53rd with a total score of 48.09. A year earlier, the country was ranked 46th in the ranking. Such a fall is caused by the weakening of Ukraine's position in 6 out of the 7 components of this index (Table 1). 
Ukraine's place in Bloomberg Innovation Index in 2018-2019

\begin{tabular}{|l|c|c|}
\hline \multicolumn{1}{|c|}{ Metrics of the Bloomberg Innovation Index } & $\mathbf{2 0 1 8}$ & $\mathbf{2 0 1 9}$ \\
\hline \multicolumn{1}{|c|}{$\mathbf{2}$} & $\mathbf{2}$ & $\mathbf{3}$ \\
\hline Overall rank & 46 & 53 \\
\hline $\begin{array}{l}\text { Research and development intensivity (R\&D expenditure } \\
\text { relative to GDP) }\end{array}$ & 47 & 54 \\
\hline Productivity & 50 & 60 \\
\hline $\begin{array}{l}\text { High technology's entry (the percentage of high-tech companies } \\
\text { in the total number of enterprise) }\end{array}$ & 32 & 37 \\
\hline $\begin{array}{l}\text { Research personnel concentration (professionals working in } \\
\text { R\&D per 1 million population) }\end{array}$ & 46 & 46 \\
\hline $\begin{array}{l}\text { Manufacturing value added (added manufacturing value in } \\
\text { relation to GDP) }\end{array}$ & 48 & 58 \\
\hline $\begin{array}{l}\text { Efficiency of the postsecondary education (number of secondary } \\
\text { graduates enrolled in postsecondary institutions as a percentage } \\
\text { of cohort) }\end{array}$ & 21 & 28 \\
\hline Patent activity & 27 & 35 \\
\hline
\end{tabular}

(Legend: R\&D - Research and development, GDP - gross domestic product)

Source: Pysarenko T. V., Kvasha T. K. ta in. (2019) Stan innovacijnoji dijaljnosti ta dijaljnosti u sferi transferu tekhnologhij v Ukrajini u 2018 roci: analitychna dovidka [State of Innovation and Technology Transfer Activity in Ukraine in 2018: Analytical Reference]. Kiev: UkrINTEI. (in Ukrainian)

However, it is worth noting that this year there were 10 new countries in the rating, which were not presented in last year's version of the rating. At the same time, 4 of them (Slovenia, Brazil, United Arab Emirates and Argentina) are ranked higher than Ukraine and actually pushed it outside the TOP-50.

Ukraine still retains its intellectual potential. Our country is one of the eight countries of the world, capable to provide a complete cycle of designing and production of aerospace technology, is among the five countries of the world with a complete cycle of production of tanks and one of the ten largest shipbuilding countries of the world. In our country, high-tech industries are developed, in particular, the manufacture of heavy machinery, power engineering equipment, instrumentation and medical equipment, with the highest number of patent applications [2].

In addition, Ukraine has a relatively high level of education, significant intellectual potential of the population is achieved due to the developed 
system of higher education and training of research personnel. The country has world-renowned scientific schools for mathematics, informatics, physics, chemistry, medicine, nuclear physics, radio electronics, biotechnology, development of new materials, information technologies, communications and telecommunications, etc. Ukraine has a strong mineral base, experience and established channels of promotion.

Table 2 shows the number of enterprises engaged in innovation activities in Ukraine in 2017.

Table 2

Number of enterprises engaged in innovation activities in Ukraine in $\mathbf{2 0 1 7}$

\begin{tabular}{|l|c|}
\hline & Number of enterprises \\
\hline Total & 759 \\
\hline out of them & 631 \\
\hline had the expenditures on innovation activities & 672 \\
\hline implemented innovations & 358 \\
\hline out of them & 456 \\
\hline introduced innovative products & 450 \\
\hline introduced new processes & \\
\hline $\begin{array}{l}\text { implemented innovative products that have been } \\
\text { re-introduced or have undergone significant technological } \\
\text { changes over the last three years }\end{array}$ & \\
\hline
\end{tabular}

Source: Ershova G.V. (2017) Innovatsiyna diyal'nist'v Ukraïni: osnovni tendentsiï ta problemi [Innovative activity in Ukraine: main tendencies and problems]. Ekonomika $i$ prognozuvannya, no 4, pp. 137-148.

As far as the types of economic activity are concerned, the highest share of innovative enterprises in Ukraine was in the enterprises of information and telecommunications $(22.1 \%)$, processing industry $(21.9 \%)$, financial and insurance activities (21.7\%) and activities in the field of architecture and engineering $(20.1 \%)$. At the same time, the share of enterprises with technological innovations was higher than the national average among the enterprises of manufacturing (15.6\%), supply of electricity, gas, steam and air-conditioning (12.6\%), as well as enterprises engaged in activities in the field of architecture and engineering, research and development, advertising - 13.2\%; with non-technological innovations - among financial 
and insurance enterprises (18.0\%), information and telecommunications $(17.3 \%)$, processing industry $(15.3 \%)$ [11].

The highest level of innovation activity was observed at the enterprises of Rivne, Kharkiv and Kyiv regions.

The highest share of technologically innovative enterprises is in Rivne (19.1\%), Kharkiv (18.7\%) and Kirovograd (14.7\%) regions; non-technologically innovative enterprises - in Kyiv (17.8\%), Ivano-Frankivsk and Kyiv oblasts (both 15.1\%) [11].

In 2017 in Ukraine, enterprises spent 9.1 billion UAH on innovations, including the purchase of machines, equipment and software -5.9 billion UAH, and on internal and external research -2.2 billion UAH, on acquisition of other external knowledge (acquisition of new technologies) 0.02 billion UAH and on other works related to creation and implementation of innovations (other expenses) - 1.0 billion UAH.

In $2017,88.5 \%$ of industrial enterprises, which were active in innovations, in Ukraine implemented innovations (or 14.3\% of surveyed industrial enterprises). Table 2 shows the number of enterprises, which implemented the innovationby type of innovation and by region [6].

The largest number of industrial enterprises actively introducing innovations in their activities is in the city of Kharkiv and Kharkiv region - 105, on the second place is the city of Kyiv -73 , followed by Lviv region 47 enterprises.

Table 3 shows ukrainian industrial enterprises, which implemented the innovations, by the types of innovations and regions.

The analysis of the documents of the State Statistics Service of Ukraine showed that $17 \%$ of entrepreneurs in Ukraine do not have good reasons to carry out innovative projects for a number of reasons, namely: low demand for innovation on the market; low company competition on the market, and lack of good ideas or opportunities for innovation [11].

This is evidence that the enterprise lacks or underdeveloped innovative management. The rest of the entrepreneurs, accounting for $83 \%$, believe that certain factors of the business environment hindered them from development of the innovative projects. An analysis of the literature $[3 ; 9 ; 12]$ made it possible to identify the main ones, namely:

1. Financial and economic: structural deformation of the Ukrainian economy, dominance of raw materials and industries with low levels of 
Table 3

Ukrainian industrial enterprises, which implemented the innovations, by the types of innovations and regions

\begin{tabular}{|c|c|c|c|c|c|c|}
\hline & \multicolumn{6}{|c|}{ Including implemented } \\
\hline & \multirow[b]{2}{*}{ 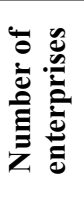 } & \multirow[b]{2}{*}{ 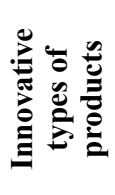 } & \multicolumn{2}{|c|}{ out of them } & \multirow[b]{2}{*}{ 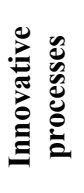 } & \multirow[b]{2}{*}{ 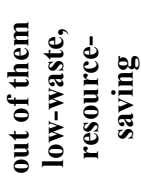 } \\
\hline & & & 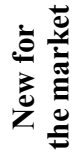 & Z & & \\
\hline Ukraine & 672 & 358 & 90 & 302 & 456 & 198 \\
\hline Vinnytsia region & 15 & 11 & 5 & 10 & 8 & 5 \\
\hline Volyn region & 16 & 4 & 1 & 3 & 8 & 5 \\
\hline Dnipropetrovsk r. & 46 & 18 & 5 & 16 & 40 & 11 \\
\hline Donetsk region & 22 & 12 & 3 & 11 & 19 & 11 \\
\hline Zhytomyr region & 23 & 9 & 1 & 8 & 10 & 3 \\
\hline Zakarpattia region & 12 & 4 & - & 4 & 7 & 6 \\
\hline Zaporozhye region & 37 & 26 & 6 & 22 & 21 & 7 \\
\hline Ivano-Frankivsk region & 23 & 15 & - & 15 & 16 & 10 \\
\hline Kyiv region & 37 & 16 & 4 & 14 & 28 & 4 \\
\hline Kirovograd region & 15 & 12 & 2 & 10 & 9 & 6 \\
\hline Lugansk region & 5 & 3 & - & 3 & 4 & 3 \\
\hline Lviv region & 47 & 24 & 8 & 20 & 40 & 12 \\
\hline Mykolaiv region & 16 & 8 & 3 & 5 & 8 & 2 \\
\hline Odessa region & 35 & 15 & 3 & 13 & 28 & 22 \\
\hline Poltava region & 23 & 15 & 1 & 14 & 13 & 2 \\
\hline Rivne region & 7 & 3 & - & 3 & 6 & 2 \\
\hline Sumy region & 18 & 17 & 8 & 12 & 8 & 5 \\
\hline Ternopil region & 25 & 7 & 2 & 5 & 23 & 4 \\
\hline Kharkiv region & 105 & 55 & 17 & 44 & 68 & 38 \\
\hline Kherson region & 15 & 11 & 3 & 11 & 11 & 2 \\
\hline Khmelnytsky region & 8 & 3 & - & 3 & 6 & 2 \\
\hline Cherkasy region & 31 & 15 & 3 & 13 & 19 & 7 \\
\hline Chernivtsi region & 8 & 7 & - & 7 & 6 & 4 \\
\hline Chernihiv region & 10 & 7 & 2 & 5 & 9 & 6 \\
\hline The City of Kyiv & 73 & 41 & 13 & 31 & 41 & 19 \\
\hline
\end{tabular}

Source: Kislenko O. (2017) Innovacijna dijaljnistj promyslovykh pidpryjemstv u 2017 roci [Innovative activity of industrial enterprises in 2017]. Ukrstat.org - publykacija dokumentiv Derzhavnoji Sluzhby Statystyky Ukrajiny. Retrieved from: https://ukrstat.org/ uk/druk/publicat/kat_u/publnauka_u.htm (accessed 27 october 2019). 
processing, which naturally have relatively low potential for innovation activity and efficiency; lack of own financial resources in the majority of domestic entrepreneurs in solving innovative development issues; lack of the own investment resources to finance innovation developments and projects; lack of credit or private capital; difficulties in obtaining state aid or subsidies for innovation; loss of a range of markets.

2. Political and legal: the uncertainty of the political situation in the country; anti-terrorist operation in eastern Ukraine; lack of legislative mechanism of the effective protection of intellectual property, as well as objective information on the country's intellectual potential; the imperfection of the legislation on taxation of enterprises producing innovative products; the existence of restrictions on patent licensing legislation.

3. Human: demographic crisis in the country (aging of able-bodied population); shortage of skilled personnel; outflow of qualified personnel abroad; decrease in labor activity of the population due to the low labor costs; the lack of an effective system of advanced training and experience of organizing the work of employees in terms of innovative development; low level of perception of innovations by the population; the structure of professions and specialties that are currently being trained in the educational institutions does not fully correspond to the structure of labor market needs.

4. Technological: outdated technologies and high level of deterioration of fixed assets; obsolescence of the technological base; low productivity; high dependence on high-tech imports; high degree of dependence on energy resources imports; lack of conformity of national technical standards with international practice, which is a barrier for expanding foreign markets.

5. Organizational and infrastructural: inadequacy of the existing system of production organization and level of management to the tasks of innovative development; orientation of entrepreneurs on already existing markets and short-term return on innovation; mismatch of innovative processes participants' interests; lack of partners for cooperations; low level of research and development results' capitalization; underdevelopment of innovative infrastructure.

\section{The essence and functions of innovation management}

The success of innovative activities is driven by the innovation management. Innovation management is considered in several aspects as: science and art of innovation management (I. Dychkivska, P. Zavlin); type of 
management activities for decision-making on innovation (I. Balabanov, M. Yokhna, V. Stadnik,); apparatus for management of innovations (N. Kruglova, A. Porshnev); system of rules, principles, norms, value orientations governing different spheres of innovative activity (V. Vasilenko, L. Oholeva).

Innovation management is dominated by the methods of social and psychological range, heuristic and collegial (I. Ansoff, B. Gates, L. Karamushka, A. Morita). There is a change in the general functions, structure and goals of management (L. Danilenko, L. Oholeva), and there are special means and forms of organization of innovative activity (V. Vasilenko, L. Vashchenko). An important place in the innovation management belongs to the project activity (A. Porshnev, N. Solomatin, V. Ustinov) [7].

The main goals of innovation management include: accumulation of innovative, forward-looking ideas; bringing innovative ideas to the level of a finished product or technology; stimulating employees to the personal and collective creative development for the benefit of the organization.

Main functions of the innovation management include:

1. Organization (identifying the needs of the modern market; establishing an area of innovation that is the most relevant to the interests of the enterprise; active introduction of innovation; uniting the innovative and creative efforts of highly qualified specialists, employees of all categories with high levels of education and intellectual development, who can be characterized by analytical thinking, so as to offer interesting independent thoughts, new ideas; organizing strategic units in the enterprise for selection of the viable innovations).

2. Planning (planning the possible changes in market requirements for innovative products in the future through the understanding what to expect from tomorrow; planning the innovative potential of the organization, production opportunities; planning the career of creative workers; R\&D of new technologies, new product models).

3. Motivation (providing the effective work of the staff (in terms of role distribution, personal relationships, etc.); material and intangible motivation for the employees' innovative creativity; formation of the loyalty, staffs' trainings on the creative working methods).

4. Control and evaluation (to control the execution of works, their compliance with the organization's goals, time and financial constraints; evaluation of the effectiveness of innovative projects, innovative managerial decisions, 
innovations applied; preparation and implementation of decisions aimed at achieving the intended development goals and overcoming deviations).

\section{Creative managers in innovation management}

The role of the manager increases during innovation activities. He must be a creative personality, because that is the kind of person who will use and support innovation management.

The practice of modern management shows that creative managers are more efficient, flexible, more profitable and have significant competitive advantages. It is necessary to emphasize the possibility of non-standard solution of standard management problems or crises that arise in economic systems through the work of creative managers. It should be noted that this branch of management activity in Ukraine is still quite new and faces a considerable number of problems, which diminishes its effectiveness and attractiveness for active implementation in government processes at the state and individual entities level.

In the modern conditions of the management science's development and practice in Ukraine, one of the main tasks is to identify and systematize problems in the development of domestic managers creativity, because due to the identification of the problems in the development of creativity, it will be possible to locate them, develop appropriate mechanisms of elimination and gain additional competitive advantages at the state level and individual business structures.

One of the important groups of managers' creativity development in Ukraine is organizational problems. This group of problems was caused by the lack of practice in organizing, stimulating and training creative managers in Ukraine. This group of problems is characteristic for the state level as well as the level of individual enterprises. The state has put the creative development of managers on the educational institutions and a rather chaotic system of seminars, roundtables, coaching for government officials and other public administration stakeholders. Businesses mainly focus on individual training of a manager, personal characteristics and coaching. Thus, nowadays Ukraine does not have a clear organization for the development of managers' creativity neither at the state level nor at the individual enterprises [10].

According to the scientists Y. Kalenichenko and Y. Smirnova, creative managers are distinguished by their focus on solving a number of practical managerial problems, namely: 
- assessment of the creative potential in the organization and, as a result, - creation of creative atmosphere in the team;

- formation of temporary creative teams capable of effective participation in the group creative process;

- evaluation of the dominant motivational units and the possibility of their use in the creative process;

- definition of innovative methods, operations and techniques that must be mastered for better and prompt solution of non-standard tasks [5].

Innovation managers include: executives of creative teams of performers; heads of laboratories, departments and functional services; heads of production divisions; managers of different levels, who coordinate the activities of different innovative units and external partners; heads of innovative enterprises, firms in general.

Specifics of the innovative processes, which involve many participants and interested organizations and are the subject of management, determine the specific nature of the work of managers in this field and define the fulfillment of certain roles and corresponding requirements.

The work of innovation managers is creative, requires a variety of knowledge, aptitude for analytical activity, ability to concentrate at a certain time on the identified problems. Since the main subject of the manager's work is scientific, technical and managerial information, a prerequisite for his effective work is knowledge of the modern scientific paradigm regarding information technology, moral, ethical, environmental and social problems. As the member of the RAS V. Fortov emphasizes, «science must be guided by moral laws.»

There are three categories of requirements for the professional competence of the manager-innovator in the innovation management: knowledge of theory and practice in management; interpersonal skill and ability to work with people; competence in the specialization of an innovative process or an innovative enterprise [9].

P. Mykytyuk defines the following common features of innovation managers:

1. The problematic vision of the world, the ability to recognize problems where everything is clear to others.

2. Ability to be preventative, that is, to determine problems in advance (when they are just emerging). 
3. Ability to perceive, understand and use views that are different from personal or opposite, so antinomy.

4. Expresentness - the ability to reach the right conclusions in the conditions of a lack of information.

5. Developed psychological self-regulation that determines the attitude to the problems and their evaluation.

6. Ability to imitate the functions of different team members.

7. Innovative and incoherent thinking, the ability to go beyond the formal, traditional, usual.

8. Attractiveness - the ability to engage people in joint activities by resorting to the administrative or material coercion.

9. Ability to delegate not only power and responsibility, but also the authority as a leader.

10. Ability to quickly adapt psychologically to changing conditions of activity or to a process of solving fundamentally new tasks.

11. The ability to have latent (hidden) leadership that involves engaging people not through a formal subordination basis but through communication [9].

All these traits do not exist in separately and not in a disjointed chaotic set, but in the interactional system.

The question is why innovative activities needs creative managers and creative staff? Because these people have creative thinking that gives a rise to original, non-trivial, unusual ideas.

With regard to the main problems of the development of managers' creativity, they can be divided into three levels: the state level, the level of individual business entity and individual level.

Problems of the managers' creativity development at the state level in Ukraine include: weak interest of the state in creation of creative managers' training system; ineffective education in terms of developing the creativity of future and existing managers; lack of legislative and regulatory framework for the development of managers' creativity; lack of adaptation of state institutions to the development of creativity of their own managers.

Problems of the managers' creativity development at the level of an individual business entity in Ukraine include: lack of a managers' creativity development system (selection, training, preparation, evaluation, motivation, organization); lack of stimulation for creativity development of their own managers; lack of understanding the importance of managers' creativ- 
ity development in the modern economic environment; inefficient psychological atmosphere in the team.

Individual problems of the individual managers' creativity development in Ukraine include: unwillingness to develop their own creative skills; low psychological resistance to failures during the generation of new ideas; poor educational background; poor practical training; lack of experience; inactivity in thinking; passivity [10].

\section{Creativity as the basis of innovation management}

Increased competition, the growth of financial and intellectual potential lead managers and company leaders to understanding of the need to turn to methods and sources for the creation of innovative solutions, to search for authors of innovative ideas. Such trends lead to a demand for solutions based on creativity.

Creativity - the ability to come to new, non-trivial and at the same time justified decisions.

Based on the expansion of the creative component, the features of the activity of a manager, who is engaged in innovative activities, are modified. This manifests itself in the following:

1. Independence in a decision-making is complemented by the reasonableness of the alternative choices.

2. Susceptibility to the new, capable of creating a new value, increases.

3. Ability not only to scientific, technical and industrial, but also to organizational and managerial creativity, for the materialization of various ideas, for invention develops.

4. Predisposition to the risk and willingness to take it upon themselves are complemented by the ability to develop and implement preventive measures.

5. Focus on a rapid development on an innovative basis increases.

6 . Activity not only in the economic but also in other spheres of society displays itself.

7. Ability not only to discover opportunities hidden from the others, but also to create them realizes.

8. Search for new opportunities outside of the currently controlled resources is made.

9. Intellectual fearlessness, information literacy, tolerance for information redundancy and uncertainty, ability to generate new knowledge, 
increased motivation to generate new knowledge (all that is called «intellectual entrepreneurship») develop [13].

Not every employee can be engaged in a creative work, since it requires some characteristics. So, first of all, the employee must have a desire to get engaged in a creative work, since creative work is based on the intrinsic desire of a person and to force her to get engaged in the creativity is almost impossible. Also a person must have the talent and creativity, which is needed for a creative working performance, because only due to them a person is able to create something new. But the other characteristic, which is called creativity, is necessary, it expresses an orientation of a person to the creative working performance, desire to use a creative approach in all situations. In addition, creativity includes the skills of creative working performance, presenting the result, etc. The combination of these characteristics determines a person's predisposition to a creative work.

If a person has a predisposition to creativity, she looks for the opportunity to apply her abilities and skills. It is often the case that it is the workplace where a person faces problems that can only be solved through creative work. These problems are caused by the imperfection of the enterprise, its organization of production and labor, etc. In this regard, at the first stage of creative activity, the employee shall be aware of the problem and decide to solve it.

It is followed by a creative work itself, where the employee, using all of his or her creative abilities and skills, is engaged in the process of improving or creating new ideas. The personal characteristics determine the nature of a creative work, its duration and, finally, the result. Therefore, a creative work and its result are highly dependent on the person who performs it, on her abilities, talents, motives, even outlook.

The result obtained in the process of creative working most often represents some idea, prototype, pattern and so on. But in this form, the result is difficult to be used for the enterprise, in this idea itself will not bring the corresponding effect. Therefore, the stage of implementation of the idea at the enterprise, in the process of which the corresponding changes of production, labor activity, goods and services, etc., are still necessary. Making such changes requires additional time and effort, not only to implement the idea but also to overcome the resistance to change, to prove the need and importance of this innovation. Therefore, this stage is no less important than 
the idea creation process itself, since so many ideas have remained on paper and have not passed this stage. And in the process of the creativity result implementation in the enterprise, it turns into an innovation.

\section{Education of creative managers at the entrepreneurial university}

Creative thinking is a revolutionary and constructive thinking. The main advantages of creative thinking include the following: creativity helps to solve existing problems, because it is a good idea what can help in finding a way out of a deadlock; creative thinking pushes the individual to find the most unusual ways of development; creativity makes any activity infinitely diverse; creativity allows to realize a creative plan; creativity helps to find the ways for a self-realization.

That is why creative thinking is so important for innovative managers. However, there is a problem with the training of creative managers and their creative thinking.

As far as the education system in general is concerned, it is highly conservative, especially its subsystem - universities. This can be explained by many reasons, the main is the habit of people to reproduce the method of knowledge transfer through which they have acquired the knowledge themselves. One of the important ideas regarding the transformation of the modern university, aimed at ensuring the best correspondence of the results of its activity to the requirements of time, became the concept of an entrepreneurial university.

A university wishing to be called entrepreneurial must overcome limitations in three areas: the generation of creative thinking, knowledge, constantly working on the creation of the new research methods and the study of new areas of knowledge or new problems in already known areas; teaching, developing innovative teaching methods and modifying the content of learning by reflecting the latest achievements of science and practice; putting knowledge into practice through various types of interaction with the external environment [4].

It is worth emphasizing why entrepreneurial universities are so important for the training of creative managers:

1. There is a stimulation of innovative, entrepreneurial activity of students in various forms. Classes in design and research activities, solving situational problems. The interaction of universities with Entrepreneurship 
Centers contributes to the development of academic disciplines by adding entrepreneurial modules. Some universities include entrepreneurial multimedia modules in academic disciplines, others offer training programs as an addition to the educational process.

2. The creation of innovative infrastructure in universities, namely the creation of: Development Centers, Project Centers, Business Laboratories and Business Incubators, Student Entrepreneurship Centers. All of them can either be part of the structure of the university, or managed by the third-party organizations. In the Development Centers novice entrepreneurs can gain practical skills in creating and managing a small enterprise under unstable market conditions.

3 . The creation of a research university of the entrepreneurial type. This is a university with a key goal to transform into an research university of the entrepreneurial type through the active stimulation of the entrepreneurial activity of students and employees due to activities of the Research, Development Centers, etc.

While introducing a model of an entrepreneurial university, an important component of its successful activity should be considered, namely the presence of the highly qualified managers and teachers who have a creative, innovative vision, entrepreneurial idea, strive for success, are willing to take risks and not afraid of changes.

The entrepreneurial university is a place that can make teaching a more attractive field of activity for creative people who can teach creative thinking and activities, which are the necessary elements in innovative entrepreneurship and are now so frightened of the teaching routine.

\section{Conclusion}

For the domestic economy, innovation and innovative development is the driving force that can ensure the economic independence of Ukraine and bridge the gap with developed countries. Innovation paves the way for structural adjustment on a modernized technological base. The solution of many problems of our time at the micro and macro level largely depends on the intensification of innovation. As the formation of the national innovation system, where the role of the main resources is played not by traditional factors of production: labor, capital and natural resources, but by knowledge embodied in innovations, the gap between the states only widens. Not only the living standards of the population of the country, but also the state 
integrity will depend on the resource or innovation - development path, which becomes the basis for further economic policy of Ukraine.

Only a talented creative manager, able to frame and motivate a creative team, implement and maintain innovation management at the enterprise can provide innovative development.

\section{References:}

1. Brutyan M.M. (2013). Innovatsionnyy menedzhment organizatsii proizvodstva tekhnologicheskogo novshestva [Innovation management of the production organization of the technological innovation]. Kreativnaya ekonomika, vol. 7 , no. 10, pp. 72-76.

2. Chizheskiy B., Shevchenko N. (2016). Innovatsionnoe razvitie: pochemu otsutstvuet politicheskaya volya i vvodyatsya ispolnitel'naya i finansovaya blokady? [Innovative development: why is there no political will and executive and financial blockades are introduced?]. Golos Ukrainy, no. 136 (6390). Retrieved from: http://www.golos.com.ua/rus/article/272892 (accessed 27 october 2019).

3. Ershova G.V. (2017). Innovatsiyna diyal'nist' v Ukraini: osnovni tendentsii ta problemi [Innovative activity in Ukraine: main tendencies and problems]. Ekonomika i prognozuvannya, no. 4, pp. 137-148.

4. Gel'manova Z.S., Butrin A.G., Gart N.A. (2016). Predprinimatel'skiy universitet, $\mathrm{v}$ kontekste vzaimodeystviya «troynoy spirali» [Entrepreneurial University in the context of the interaction with the "triple helix"]. Mezhdunarodnyy zhurnal prikladnykh i fundamental'nykh issledovaniy, no. 7, pp. 444-449. Retrieved from: https://applied-research.ru/ru/article/view?id=9845 (accessed 27 october 2019).

5. Kalenichenko Ju.B. (2011). Kreatyvnistj jak osnova menedzhmentu orghanizaciji [Creativity as the basis of organization's management]. Marketyngh $i$ menedzhment innovacij, vol. 2, no. 4, pp. 186-191.

6. Kislenko O. (2017). Innovacijna dijaljnistj promyslovykh pidpryjemstv u 2017 roci [Innovative activity of industrial enterprises in 2017]. Ukrstat.org - publykacija dokumentiv Derzhavnoji Sluzhby Statystyky Ukrajiny. Retrieved from: https://ukrstat.org/ $\mathrm{uk} / \mathrm{druk} /$ publicat/kat u/publnauka u.htm (accessed 27 october 2019).

7. Marmaza O.I. (2014). Innovacijnyj menedzhment v osviti: sutnistj, funkciji, zasoby [Innovation management in education: essence, functions, tools]. Pedaghoghika formuvannja tvorchoji osobystosti u vyshhij $i$ zaghaljnoosvitnij shkolakh, no. 36(89), pp. 309-316.

8. Michelle Jamrisko, Lee J Miller, Wei Lu (2019). These Are the World's Most Innovative Countries. Retrieved from: https://www.bloomberg.com/news/ articles/2019-01-22/germany-nearly-catches-korea-as-innovation-champ-u-srebounds (accessed 27 october 2019).

9. Mykytjuk P.P. (2007). Innovacijnyj menedzhment [Innovation management]. Kyiv: Centr uchbovoji literatury. (in Ukrainian)

10. Petrosov V.A. (2017). Problemy rozvytku kreatyvnosti menedzhera v Ukrajini [Problems of manager's creativity development in Ukraine]. Problemy systemnogho pidkhodu v ekonomici, no. 3(59), pp. 108-113. 
11. Prylypko R.Ju. (2016). Obstezhennja innovacijnoji dijaljnosti v ekonomici Ukrajiny za period 2014-2016 rokiv [Survey of the innovative activity in the Ukrainian economy for the period 2014-2016]. Ukrstat.org publykacija dokumentiv Derzhavnoji Sluzhby Statystyky Ukrajiny. Retrieved from: https://ukrstat.org/uk/druk/publicat/kat_u/publnauka_u.htm (accessed 27 october 2019).

12. Pysarenko T.V., Kvasha T.K. ta in. (2019). Stan innovacijnoji dijaljnosti ta dijaljnosti u sferi transferu tekhnologhij v Ukrajini u 2018 roci: analitychna dovidka [State of Innovation and Technology Transfer Activity in Ukraine in 2018: Analytical Reference]. Kiev: UkrINTEI. (in Ukrainian)

13. Smirnov V.P. (2011). Predprinimatel'skaya deyatel'nost' v usloviyakh innovatsionnogo ekonomicheskogo razvitiya [Entrepreneurial activity in the conditions of innovative economic development]. Kreativnaya ekonomika, vol. 5, no. 4 , pp. 38-43.

14. Vsemirnaya organizatsiya intellektual'noy sobstvennosti (2017) Global'nyy innovatsionnyy indeks 2017 god [Global Innovation Index 2017]. Retrieved from: http://www.wipo.int/pressroom/ru/articles/2017/article_0006.html (accessed: 15.06.2017). 